\title{
Giant atrium, giant clot: need for anticoagulation
}

\author{
Faisal Majeed, ${ }^{1}$ Murad Abdelsalam, ${ }^{2}$ Tamim Nashad, $^{2}$ Anupam A Sule ${ }^{1}$
}

- Additional material is

published online only. To view please visit the journal online (http://dx.doi.org/10.1136/ bcr-2017-222748).

${ }^{1}$ Internal Medicine, Saint Joseph Mercy Oakland, Pontiac, Michigan, USA

${ }^{2}$ Cardiology, Saint Joseph Mercy Oakland Hospital, Pontiac, Michigan, USA

\section{Correspondence to} Dr Murad Abdelsalam, Murad.abdelsalam@gmail.com

Accepted 25 October 2017

\section{DESCRIPTION}

We present a patient with medical history of atrial fibrillation, rheumatic mitral valve stenosis and ulcerative colitis who came to the emergency room with onset of bilateral lower extremity pain 2 hours prior to presentation. On examination, feet were pale, cold and pulses were absent. Patient used to be on warfarin for atrial fibrillation which was discontinued 1 month ago by his primary care physician due to recurrent bleeding. Atrial fibrillation with controlled ventricular response was seen on ECG. Emergent arterial Doppler revealed occlusion of the bilateral calf arteries at the level of the tibioperoneal trunk. Patient underwent emergent bilateral right and left groin exploration with bilateral embolectomy and thromboembolectomy. Restoration of flow with no haemodynamically significant atheromatous changes was confirmed by repeat Doppler. Echocardiography revealed severely dilated left atrium measuring $10 \mathrm{~cm} \times 7 \mathrm{~cm}$ with large left atrial thrombi (figure 1, online supplementary video 1 ) and severe mitral valve stenosis (mean gradient of $22 \mathrm{~mm} \mathrm{Hg}$, normal $<5 \mathrm{~mm} \mathrm{Hg}$ ) (figure 2). Patient was bridged with heparin and warfarin, later transferred to tertiary care hospital for bovine mitral valve replacement.

Left atrial thrombus formation is a serious complication of mitral stenosis (26\%-33\% in severe stenosis) and atrial fibrillation. Risk of left atrial thrombus increases with the presence of atrial fibrillation, left atrial size, older age and severity of mitral stenosis. ${ }^{1-3}$ Anticoagulation is the first line therapy for left atrial thrombi. However, more aggressive measure like thrombolysis or surgical intervention might be needed if medical therapy fails or when the thrombus extends into the left atrial body. ${ }^{3}$

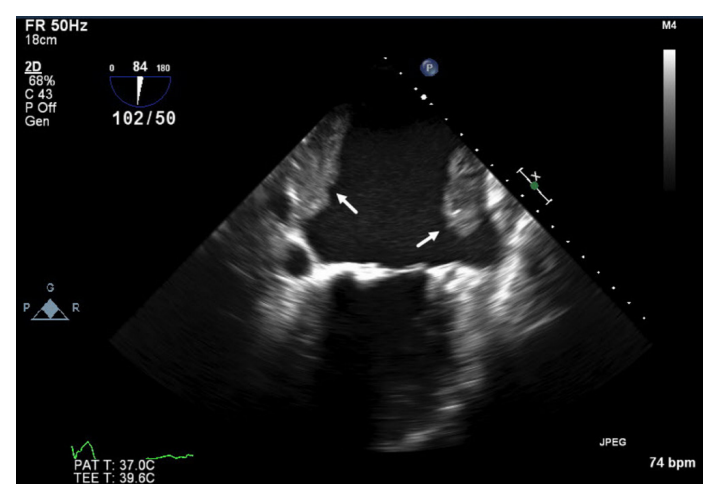

Figure 1 Transoesophageal echocardiogram, two chamber view, showing severely dilated left atrium with multiple thrombi in the left atrial body (arrows).

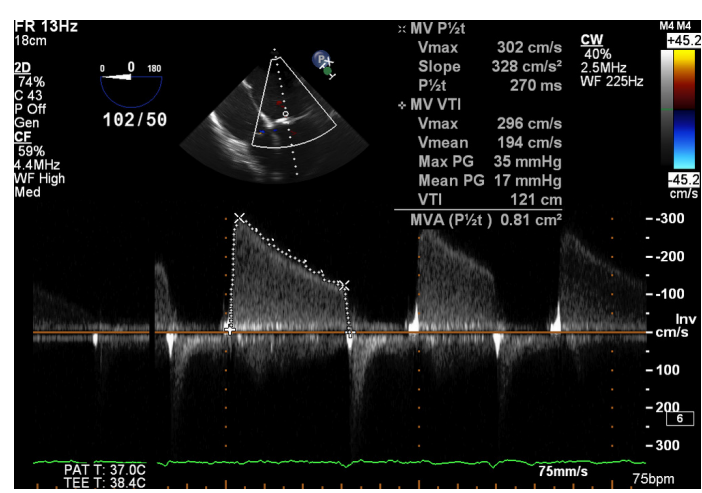

Figure 2 Continuous wave Doppler echocardiography across the mitral valve showing increased transmitral flow velocity $(3 \mathrm{~m} / \mathrm{s})$ and mean gradient $(17 \mathrm{~mm} \mathrm{Hg})$.

Repeat transoesophageal echocardiogram is usually required for follow-up when medical therapy is pursued to ensure complete resolution of thrombus.

\section{Learning points}

- Left atrial thrombi are present in a third of the patients with severe rheumatic mitral stenosis and atrial fibrillation.

- Systemic embolisation is not an uncommon presenting feature of left atrial thrombus.

- Echocardiography is an excellent diagnostic modality for left atrial thrombus.

Contributors MA and FM wrote the initial manuscript. TN and AAS conducted the literature review and edited the paper, including image editing and paper design. FM and TN contributed to data collection and image editing as well. All authors read and approved the final manuscript.

Competing interests None declared.

Patient consent Detail has been removed from this case description to ensure anonymity. The editors and reviewers have seen the detailed information available and are satisfied that the information backs up the case the authors are making.

Provenance and peer review Not commissioned; externally peer reviewed.

(C) BMJ Publishing Group Ltd (unless otherwise stated in the text of the article) 2017. All rights reserved. No commercial use is permitted unless otherwise expressly granted.

\section{REFERENCES}

1 Conradie C, Schall R, Marx JD. Left atrial size--a risk factor for left atrial thrombi in mitral stenosis. Clin Cardiol 1995;18:518-20.

2 Bollmann A, Husser D, Stridh M, et al. Atrial fibrillatory rate and risk of left atrial thrombus in atrial fibrillation. Europace 2007;9:621-6.

3 Srimannarayana J, Varma RS, Satheesh S, et al. Prevalence of left atrial thrombus in rheumatic mitral stenosis with atrial fibrillation and its response to anticoagulation: a transesophageal echocardiographic study. Indian Heart J 2003;55:358-61. 
Copyright 2017 BMJ Publishing Group. All rights reserved. For permission to reuse any of this content visit http://group.bmj.com/group/rights-licensing/permissions.

BMJ Case Report Fellows may re-use this article for personal use and teaching without any further permission.

Become a Fellow of BMJ Case Reports today and you can:

- Submit as many cases as you like

- Enjoy fast sympathetic peer review and rapid publication of accepted articles

Access all the published articles

- Re-use any of the published material for personal use and teaching without further permission

For information on Institutional Fellowships contact consortiasales@bmjgroup.com

Visit casereports.bmj.com for more articles like this and to become a Fellow 